\title{
ALAT TULANG SITUS PLESTOSEN JAWA: BAHAN BAKU, TEKNOLOGI, DAN TIPOLOGI (Bone tools from Pleistocene Site of Java: Raw Materials, Technology, and Typology)
}

\section{Ilham Abdullah}

Balai Pelestarian Situs Manusia Purba Sangiran, Jalan Sangiran Km 4, Krikilan, Kalijambe, Sragen 57275, Telepon: (0271) 6811463, Faksimile: (0271) 6811497,

e-mail: Ilhamabdullah9969@gmail.com

\section{INFO ARTIKEL}

\section{Histori artikel:}

Diterima 10 September 2015

Direvisi 17 September 2015

Disetujui 4 Oktober 2015

\section{Keywords:}

Bone tools,

Pleistosen, raw material,

technology, and tipology.

Kata kunci:

Alat tulang,

Plestosen, bahan baku,

teknologi, dan tipologi

\begin{abstract}
During this time knowledge about Homo erectus bones tool comes only from trusted Ngandong, but now it has a lot of bone tools found and published on the Site Pleistocene in Java. This paper is the result of a data-base processing using microscopic methods against all findings bone tools from sites Pleistocene in Java which aims to provide comprehensive information about the presence of bone tools. A total of 48 specimens of bone tools findings of Sangiran, Ngandong Site, Site Sambungmacan, Patiayam Site and Site Bringin. The analysis showed that there are 12 types of anatomical components of animal bones were used as tools. Type of animal bones were used as a bone tool is Cervus sp. (deer), Cervus hippelaphus (deer), Sus sp. (pig), Bos sp. (cow), Bibos palaeosondaicus (bull), rhinoceros (rhinoceros), Elephantidae (the elephants), and Bovidae. The technique used in making bone tools are broken techniques, pruning techniques, techniques sides, press techniques, and techniques rub. This type of tool is produced bone knife, lancipan, spatula, and spear.
\end{abstract}

\begin{abstract}
Abstrak
Selama ini pengetahuan tentang alat tulang Homo erectus hanya berasal dari Situs Ngandong tetapi sekarang ini telah banyak alat tulang ditemukan dan dipublikasikan dari Situs Plestosen di Jawa. Tulisan ini merupakan hasil pengolahan data-base menggunakan metode mikroskopis terhadap semua temuan alat tulang dari situs-situs Plestosen di Jawa yang bertujuan memberi informasi komprehensif tentang keberadaan alat tulang. Sebanyak 48 spesimen alat tulang temuan dari Situs Sangiran, Situs Ngandong, Situs Sambungmacan, Situs Patiayam, dan Situs Bringin. Hasil analisis menunjukkan bahwa terdapat 12 jenis komponen anatomis binatang yang digunakan sebagai alat tulang. Jenis binatang yang tulangnya digunakan sebagai alat tulang adalah Cervus sp. (rusa), Cervus hippelaphus (rusa), Sus sp. (babi), Bos sp. (sapi), Bibos palaeosondaicus (banteng), rhinoceros (badak), elephantidae (gajah), dan bovidae. Teknik yang digunakan dalam membuat alat tulang adalah teknik pecah, teknik pangkas, teknik belah, teknik tekan, dan teknik gosok. Jenis alat tulang yang dihasilkan adalah pisau, lancipan, spatula dan mata tombak.
\end{abstract}

\section{PENDAHULUAN}

Artefak yang berkaitan dengan kehidupan Homo erectus adalah sebuah hal yang sangat menarik untuk dibahas, salah satunya adalah alat yang terbuat dari tulang binatang. Data temuan memperlihatkan bahwa, pada tingkat Plestosen Bawah hingga kala Plestosen Tengah Homo erectus di Jawa, lebih dominan menggunakan peralatan dari batu. Lalu kemudian pada Plestosen Akhir muncul penggunaan peralatan yang terbuat dari tulang dan tanduk binatang (Soejono dalam Notosusanto, 2010:93-94).

Pembuatan alat-alat tulang pada tingkat Plestosen sementara ini hanya diketahui di Ngandong sebagai unsur yang ditemukan dalam konteks Pithecantrhopus soloensis dan alat-alat lain yang dibuat dari tanduk, serpih, batu-batu bundar. Alat-alat tulang, yang berupa sudip dan mata tombak yang bergerigi pada kedua sisinya, 
berukuran panjang $9,5 \mathrm{~cm}$. kedudukan alat tulang ini ditemukan dalam satu hubungan dengan Pithecantrhopus soloensis. Alat-alat dari tanduk menjangan memperlihatkan bagian yang diruncingkan.Duri ikan pari ditemukan pula pada situs ini dan benda ini mungkin digunakan sebagai mata tombak (Soejono dalam Notosusanto, 2010:132-133).

Sementaraitu, beberapa temuan alat tulang dari berbagai Situs Plestosen di Jawa telah dipublikasikan. Diantaranya adalah di Situs Sangiran telah dipublikasikan penemuan sejak tahun 1980an berupa sebuah kapak perimbas (chopper) yang terbuat dari gading (tusk) Stegodon pada formasi Kabuh berumur 800.000 BP yang ditemukan di Bukit Ngebung pada kegiatan ekskavasi oleh tim Indonesia-Perancis. Kemudian pada tahun 1995-1997 telah dipublikasikan empat buah alat tulang berupa alat yang terbuat dari tulang kering Bovidae, alat tulang binatang, sebuah pisau yang terbuat dari tulang rusuk gajah (costae elephantidae), dan Sebuah lancipan besar yang terbuat dari tulang telapak kaki depan badak. Sebanyak 33 buah alat-alat tulang dari Situs Sangiran hingga tahun 2013 telah penulis rangkum dan publikasikan (Abdullah 2013 dan 2014).

Publikasi berikutnya berasal dari daerah Tegal Rejo, Desa Dero yang merupakan bagian dari Situs Bringin, Kabupaten Ngawi telah ditemukan sebuah spatula terbuat dari tulang tibia Cervidae (rusa) berkonteks kabuh Plestosen tegah. Publikasi terakhir mengenai alat tulang di Jawa adalah alat tulang yang ditemukan bersama empat buah artefak lainnya yaitu tiga buah kapak perimbas (chopper) dan sebuah batu pukul (Siswanto dalam Anonim, 2014:23).

\section{TUJUAN}

Berdasarkan catatan penemuan dan publikasi alat tulang dari situssitus Plestosen di Jawa, maka penulis mencoba untuk merangkum dan mengkomunikasikan temuan alat tulang tersebut.Walaupun jumlahnya masih terbatas, setidaknya tulisan ini memberikan informasi bahwa beberapa situs Plestosen di Jawa mengandung alat tulang, bukan hanya Situs Ngandong. Alat tulang yang penulis tampilkan kali ini mengandung informasi mengenai bagian tulang binatang yang digunakan sebagai bahan baku, teknologi pembuatannya, jenisnya dan di situs mana saja lokasi penemuannya. Hasil publikasi ini akan dimasukkan ke dalam data base alat tulang kala Plestosen di Indonesia, melanjutkan data base temuan alat tulang dari Situs Sangiran.

\section{PERMASALAHAN}

Beberapa temuan alat tulang yang berasal dari situs-situs Plestosen di Jawa telah dipublikasikan oleh para peneliti, namun belum mendapatkan perhatian khusus. Kemungkinan jumlahnya yang masih sedikit dan publikasi itu terpisah secara sendiri-sendiri serta tidak adanya komunikasi antara peneliti.

Walaupun telah diyakini bahwa Homo erectus di Jawa lebih banyak menggunakan peralatan yang 
berbahan organik (bambu, kayu, dan tulang binatang), tetapi hingga saat ini nampaknya temuan alat berbahan batu masih dominan dibandingkan dengan alat berbahan organik (Simanjuntak dan Widianto, 2012:100). Hal tersebut yang menyebabkan sebagian besar peneliti beranggapan bahwa sulit untuk menemukan alat tulang, kayu, dan bambu yang berbahan organik, seandainya artefak tersebut terkonservasi dengan baik atau menjadi fosil, maka pasti sulit untuk dikenali. Hal tersebut diakibatkan oleh tingkat pembundaran, pengelupasan, dan patinasi yang sangat tinggi sehingga jejak teknologi yang terdapat pada fosil alat tulang dan bahan organik lainnya akan mengalami kerusakan atau tidak nampak. Permasalahan dalam tulisan ini adalah bagaimana bahan baku, teknologi dan tipologi alat tulang situs Plestosin di Jawa?

\section{METODE}

Metode yang penulis gunakan dalam mengidentifikasi alat tulang adalah dengan pengamatan makroskopis. Pengamatan ditujukan pada bagian permukaantulangyang memperlihatkan jejak kerusakan. Jejak pada tulang biasanya berupa jejak pemukulan dan jejak pemotongan. Tulang yang pecah akibat pemukulan akan meninggalkan bekas berupa titik pukul, karakteristik dari titik pemukulan adalah adanya wilayah pukul yang memiliki morfologi lekukan melingkar atau setengah lingkaran pada permukaan tulang dengan bentuk tepian bergerigi ataupun bertingkat, namun tetap memiliki kesamaan dengan permukaan kulitya.
Jejak pemotongan akan meninggalkan bagian yang rata pada permukaannya dengan memperlihatkan bagian dalam tulang (Lyman, 1987, dalam Kusno, 2006: 19-21).

\section{HASIL DAN PEMBAHASAN}

\section{Situs-Situs Alat Tulang di Jawa}

Berikut ini penulis uraikan mengenai situs-situs Plestosen di Jawa yang mengandung temuan alat tulang dilengkapi deskripsi bahan, teknologi, dan jenis alat tulangya. Alat tulang tersebut diperoleh dari berbagai sumber, yaitu sumber pustaka yang telah diterbitkan oleh para peneliti dan hasil penelitian yang kami lakukan sendiri. Penomoran terhadap alat tulang tersebut untuk memudahkan penghitungan dalam data base, bukan berdasarkan urutan penemuan maupun usia. Situs-situs alat tulang tersebut adalah:

\section{Alat tulang dari Situs Sangiran}

Situs Sangiran terletak di Kabupaten Sragen dan Kabupaten Karanganyar, JawaTengah. Situs Sangiran merupakan sebuah kawasan dengan luas 59,21 $\mathrm{km}^{2}$. Situs ini memiliki singkapan tanah alamiah yang memperlihatkan perubahan lingkungan, jenis binatang, manusia purba dan budayanya dimulai sejak sekitar 2,4 hingga 0,1 juta tahun lalu. Bermula dari lingkungan laut, rawa, kemudian menjadi daratan.

Penemuan alat tulang di Sangiran sebenarnya telah dipublikasikan sejak tahun 1980-an, namun publikasi itu masih terpisah secara sendiri-sendiri. Pada tahun 2013 dan tahun 2014, 
telah dicoba merangkum semua temuan alat tulang dari Sangiran. Terdapat 33 spesimen alat tulang yang telah dipublikasikan. Temuan tersebut berasal dari sumber pustaka publikasi dari para peneliti, temuan penduduk, dan koleksi BPSMP Sangiran.

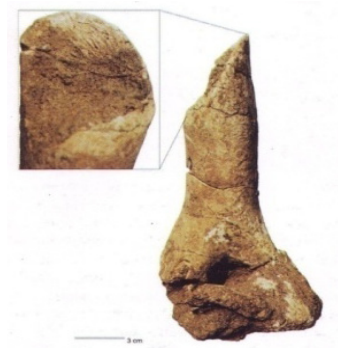

Gambar 1. Alat nomor

6: lancipan terbuat dari lengan atas

Banteng (Sumber:

Budiman dkk, 2011:73

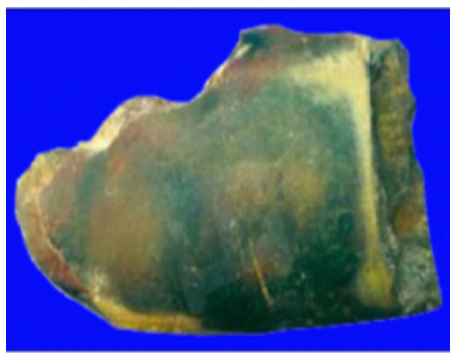

Gambar 2. Kapak perimbas terbuat dari gading gajah. Alat tulang no. 26 (Sumber: Semah, 2006 dalam Fauzi dkk, 2013)

\section{Alat tulang dari Situs Ngandong}

Situs Ngandong terletak di Desa Lebak, Kecamatan Kraden, Kabupaten Blora, Jawa Tengah. Alat tulang yang telah dipublikasikan oleh Oppenorth pada sekitar tahun 1930-an yang berhasil penulis lacak berupa dua buah alat tulang yaitu sebuah tombak yang terbuat dari duri ikan pari dan sebuah tanduk rusa bercabang yang memiliki lancipan pada salah satu ujungnya. Namun demikian penulis tidak menemukan ukuran pada deskripsi yang dicantumkan oleh Oppenorth. Penulis juga tidak melakukan pengukuran karena dua spesimen itu tidak diketahui tempat konservasinya. Alat tulang nomor 34 adalah sebuah mata tombak yang terbuat dari duri ikan pari. Mata tombak ini bergerigi pada kedua sisinya, berukuran panjang $9,5 \mathrm{~cm}$ (Soejono dalam Notosusanto, 2010:132).

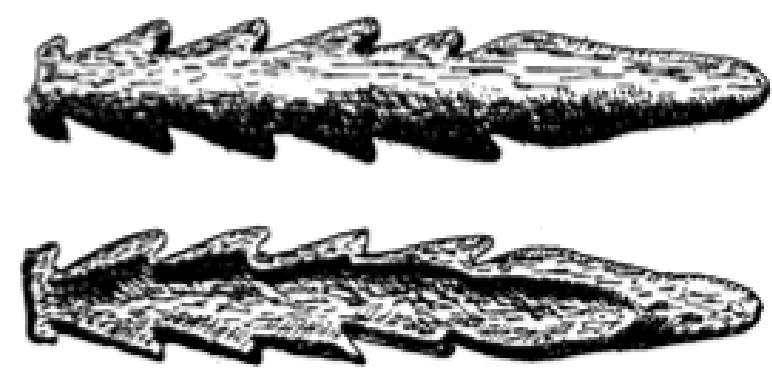

Mata tombak terbuat dari duri ikan pari.

(Gambar 4. Sumber: Oppenorth dalam Heekeren 1972 dalam Fauzi dkk, 2012:4)
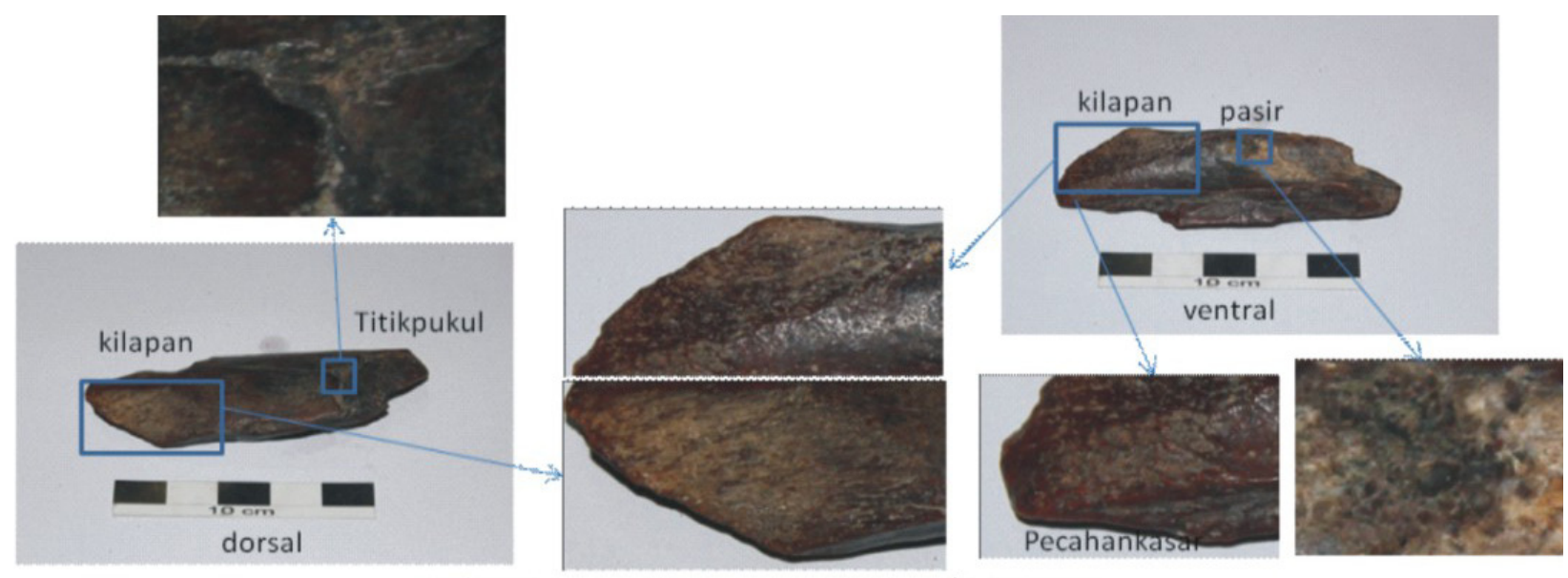

Gambar 3. Alat tulang nomor 22 (dokumentasi Ilham) 


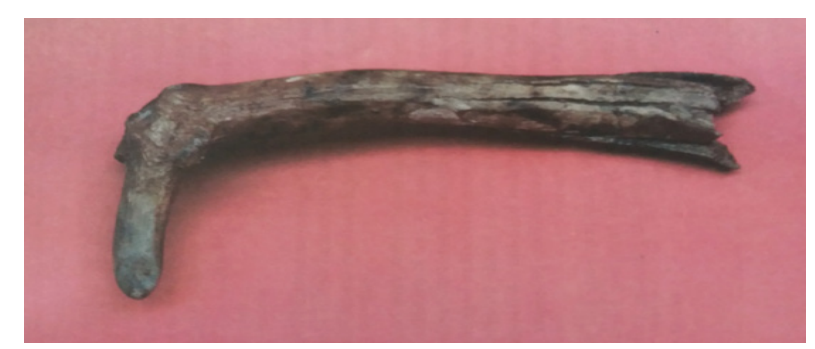

Gambar 5. Lancipan terbuat dari tanduk rusa (Sumber: Soejono, 2010:131dan 174)

Alat tulang nomor 35 adalah sebuah lancipan yang terbuat dari tanduk rusa.Tempat konservasi spesimen ini tidak diketahui, sehingga penulis tidak melakukan deskripsi ukuran dan teknologi. Selain alat tulang yang telah dipublikasikan dan diperkenalkan oleh Oppenorth pada sekitar tahun 1930an, akhir-akhir ini telah ditemukan beberapa spesimen alat tulang pada lapisan endapan teras di Ngandong. Tiga buah spesimen alat tulang telah ditemukan oleh Balai Pelestarian Situs Manusia Purba Sangiran di kotak ekskavasi pada tahun 2010 (Widianto, 2010:26-28).

Berikut deskripsi tiga buah alat tulang tersebut: alat tulang nomor 36 berupa lancipan yang terbuat dari tulang telapak kaki sebelah kiri (proximal metatarsal sinistra) Bovidae. Ditemukan pada kotak TP 1 dengan nomor urut temuan 27. Spesimen ini memiliki ukuran panjang $123,12 \mathrm{~mm}$, lebar $42,07 \mathrm{~mm}$, dan tebal $42,44 \mathrm{~mm}$. Artefak ini merupakan jenis alat yang terbuat dari tulang inti, tulang utuh dipecah menjadi dua bagian. Pada bagian distal kemudian dipangkas miring pada sisi lateral kirinya sehingga menghasilkan titik pukul dengan tajaman berbentuk spiral mengarah kebagian ujung yang menghasilkan tajaman. Panjang tajaman/pangkasan adalah $52,61 \mathrm{~mm}$, dengan sudut kemiringan pangkasan sebesar $30^{\circ}$.

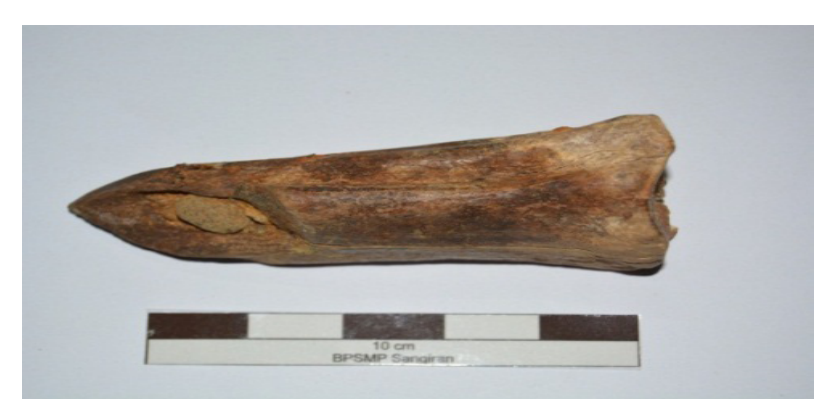

Gambar 6. Lancipan terbuat dari telapak kaki Bovidae (dokumentasi Ilham)

Alat tulang nomor 37 berupa spatula yang terbuat dari tulang hasta (proximal raidus dextra) Bovidae. Spesimen ini ditemukan pada kotak TP 1 dengan nomor urut temuan 35. Alat tulang ini memiliki ukuran panjang $121,14 \mathrm{~mm}$, lebar $58,36 \mathrm{~mm}$, dan tebal $41,98 \mathrm{~mm}$. Tulang utuh dipecah menjadi dua bagian. Bagian proximal ini kemudian dipangkas pada bagian ujung distalnya dengan satu kali pangkasan menuju ke arah ujung untuk dijadikan tajaman dengan panjang 41,58 $\mathrm{mm}$ dan dengan kemiringan pangkasan sekitar $45^{\circ}$ berbentuk spiral. Titik pemukulan terdapat pada bagian samping menuju ke arah tengah tulang. Terlihat sebuah pecahan yang lain di sebelah tajaman, namun pecahan tersebut bukan pecahan yang dibuat oleh manusia melainkan pecah secara alami sebagaimana terlihat dari permukaan pangkasan yang tidak rata.

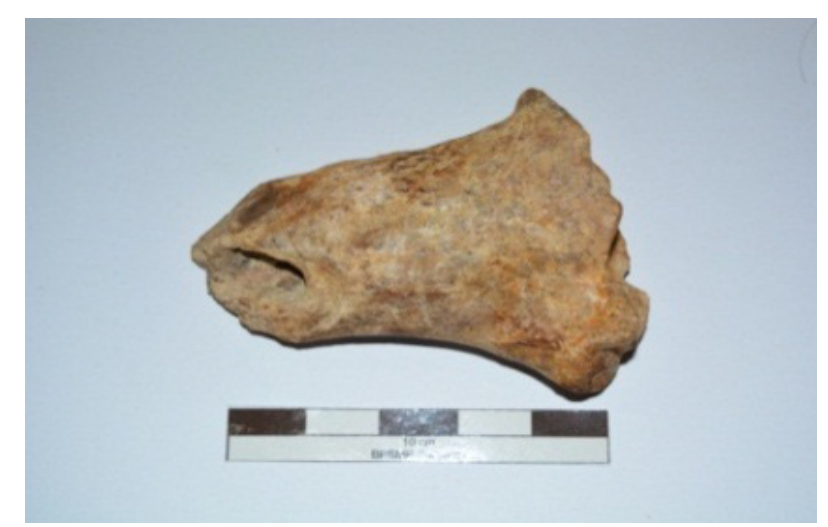

Gambar 7. Spatula terbuat dari tulang hasta Bovidae (dokumentasi llham) 
Alat tulang nomor 38 berupa lancipan yang terbuat dari tulang hasta (radius) Bovidae. Spesimen ini ditemukan di kotak ekskavasi TP 4 dengan nomor urut temuan 7. Alat tulang ini memiliki ukuran panjang $118,59 \mathrm{~mm}$, lebar $63,09 \mathrm{~mm}$, dan tebal $34,12 \mathrm{~mm}$. Alat tulang ini terbuat dari sebuah tulang segar yang dipecah jadi dua bagian. Kemudian dilakukan pangkasan untuk membentuk tajaman pada bagian distal pada sisi lateral menuju ke bagian tengah tulang sehingga terbentuk pecahan berbentuk spiral dengan panjang pangkasan $84,34 \mathrm{~mm}$ dengan sudut kemiringan $30^{\circ}$. Salah satu sisi tajaman mengalami kerusakan atau patah yang kemungkinan diakibatkan oleh alam.

Pada bagian pangkal (proximal) terlihat pecahan yang menghilangkan bagian permukaannya, namun pecahan ini terjadi secara alami karena pada permukaan pecahan terlihat tidak rata dan cenderung bergelombang.

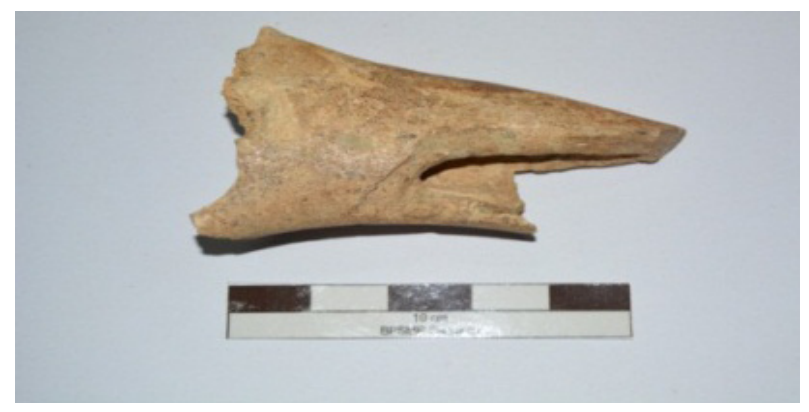

Gambar 8. Lancipan terbuat dari tulang hasta bovidae (dokumentasi llham)

\section{Alat tulang dari Situs Sambungmacan}

Situs Sambungmacan adalah sebutan untuk situs-situs yang mengandung bukti-bukti kehidupan masa purba yang berada di sepanjang meander Bengawan Solo di sekitar Desa Cemeng dan Desa Sambungmacan, Kecamatan Sambungmacan, Kabupaten Sragen,
Propinsi Jawa Tengah. Di lokasi ini telah ditemukan empat fosil manusia purba Homo erectus, tiga buah berupa fragmen tengkorak dan satu buah fragmen tulang kering (tibia). Berbagai fosil fauna telah ditemukan dari situs ini, yaitu: berbagai jenis binatang vertebrata, berbagai jenis moluska laut dan darat, Crustaseae (kepiting). Hingga saat ini, setidaknya terdapat lima buah tulang yang kami identifikasi sebagai alat tulang, berikut deskripsinya:

Alat tulang nomor 39 berupa spatula yang terbuat dari tulang panjang mamalia. Bagian yang tersisa pada tulang ini adalah bagian tengah (diaphisys). Panjang alat tulang ini adalah $121,46 \mathrm{~mm}$ dengan diameter maksimal 26,88 $\mathrm{mm}$. Pecahan pada bagian distal merupakan bagian tajaman dengan sebuah titik pukul pada pangkal pecahan. Titik pukul tersebut menghasilkan pecahan sepanjang $28,63 \mathrm{~mm}$ dengan sudut $45^{\circ}$ yang merupakan bagian tajaman alat ini. Bentuk tajaman yang dihasilkan berupa kurva melengkung (wide curved) yang lebar. Pada bagian proximal juga terdapat pecahan dengan sebuah titik pukul yang menghasilkan pecahan dengan sudut $75^{\circ}$ dan panjang $15,08 \mathrm{~mm}$.

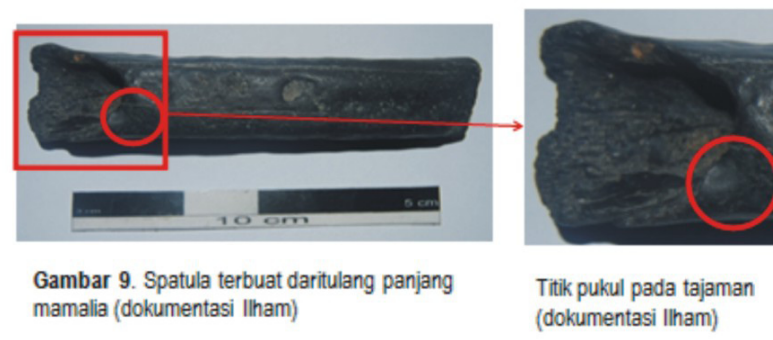

Alat tulang nomor 40 berupa lancipan yang terbuat dari tulang panjang mamalia. Fragmen tulang ini memiliki ukuran panjang $69,65 \mathrm{~mm}$, lebar $21,70 \mathrm{~mm}$, dan tebal $13,88 \mathrm{~mm}$. Fragmen tulang ini 
merupakan bagian tengah (diaphisys) tulang. Teknik pembuatannya adalah dengan cara pemotongan tulang hingga menyisakan bagian tengah, namun tidak terdapat titik pukul pada permukaan kedua sisinya. Sebuah titik pukul terlihat pada bagian ventral sebagai jejak pukul pada saat pembelahan tulang ini secara vertikal dari arah proximal-distal menjadi dua bagian. Tajaman terdapat pada ujung yang bersebelahan dengan titik pukul dan bulbus tersebut.Tajaman berbentuk lancip pada sisi ventral dan terlihat sangat halus. Tidak terdapat titik pukul pada pembuatan tajaman. Kemungkinan pembentukan tajaman pada alat ini dengan cara digosok.

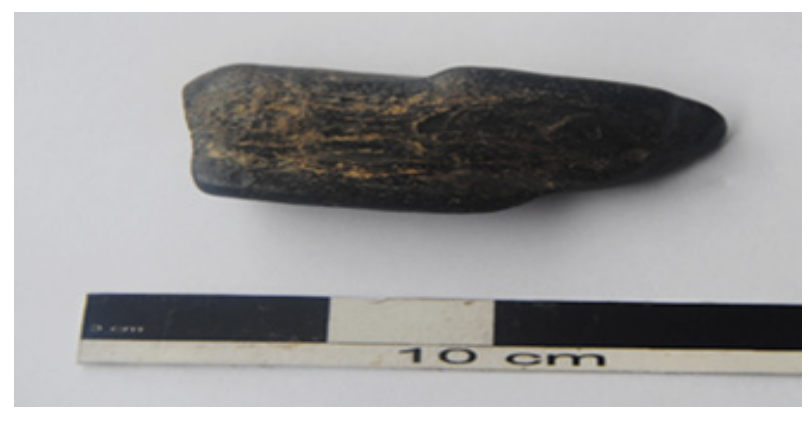

Gambar 10. Lancipan tulang terbuat dari kaki mamalia (dokumentasi Ilham)

Alat tulang nomor 41 berupa lancipan yang terbuat dari fragmen tanduk (antler) rusa (Cervus (axis) lydekkerii). Fragmen tanduk ini memiliki ukuran panjang 103,22 $\mathrm{mm}$ dengan diameter maximal 23,19 $\mathrm{mm}$. Alat ini merupakan bagian pangkal tanduk yang bercabang. Pembentukan alat lancipan diawali dengan memangkas kedua ujungnya sesuai dengan yang diinginkan. Salah satu ujung tanduk tersebut dijadikan tajaman yang dibentuk dengan cara pemangkasan langsung terhadap satu cabang tanduk pada salah satu sisinya hingga menghasilkan ujung yang runcing. Ujung yang lainnya digunakan sebagai gagang.

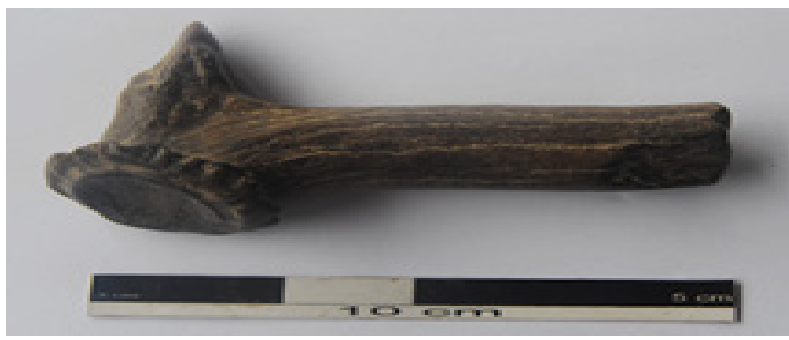

Gambar 11. Lancipan terbuat dari tanduk rusa (dokumentasi Ilham)

Alat tulang nomor 42 berupa sebuah tulang rusuk Bovidae yang dibuat menjadi lancipan. Fragmen tulang rusuk ini berukuran panjang $256 \mathrm{~mm}$, lebar $230 \mathrm{~mm}$, dan tebal $420 \mathrm{~mm}$. Terdapat pecahan pada kedua ujung tulang. Pecahan di bagian pangkal tegak lurus dengan sisi tulang, sedangkan pecahan pada bagian ujung (distal) terlihat pada bagian sisi lateral dengan kemiringan $45^{\circ}$ dan memiliki ukuran panjang 66,69 mm. Pecahan ini adalah bagian tajaman yang ujungnya berbentuk lancip.

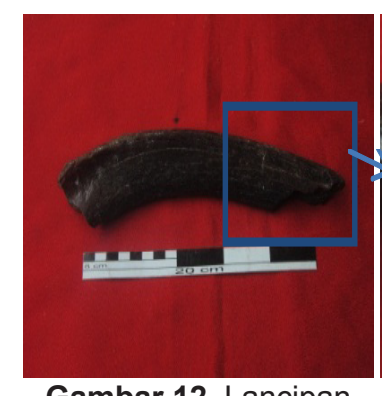

Gambar 12. Lancipan terbuat dari tulang rusuk bovidae (dokumentasi Ilham)

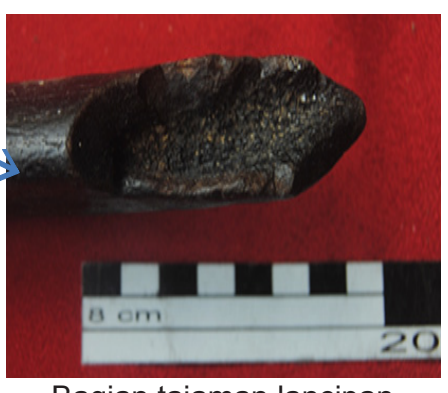

Bagian tajaman lancipan tulang (dokumentasi llham)
Alat tulang nomor 43 berupa sebuah fragmen tulang hasta sebelah kanan (radius dextra) Bovidae yang dibuat menjadi spatula. Tulang ini memiliki panjang $194,91 \mathrm{~mm}$, lebar 114,13 mm, tebal 58,39 mm. Pada salah satu sisinya terdapat sebuah titik pukul dengan arah pukulan menuju distal yang menghasilkan dua pecahan pada sisi lateralnya. Pecahan pertama sepanjang 127,11 mm dan pecahan kedua sepanjang 48,41 
mm. Pecahan pertama merupakan tajaman yang berbentuk meruncing dan melebar serta pipih. Kemiringan sudut yang dihasilkan adalah $30^{\circ}$.

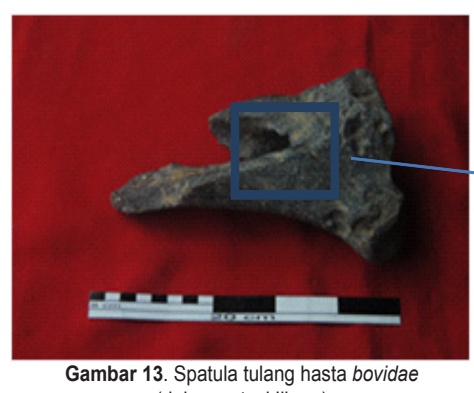
(dokumentasi llham)

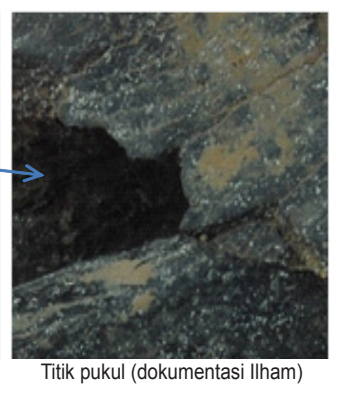

itik pukul (dokumentasi Ilham)

\section{Alat tulang dari Situs Bringin}

Situs Bringin mencakup areal di Dusun Tegalduwur, Desa Dero; Dusun Nglahar, Desa Krompol; dan Dusun Kiteran di Desa Legowetan. Potensi paleontology diketahui pertamakali pada tahun 2001. Pada situs ini telah ditemukan berbagai fosil binatang vertebrata dan alat batu yang terbuat dari sebuah kerakal yang dipangkas, dan berdasarkan ciri-cirinya dapat ditipologikan sebagai kapak perimbas. Temuan-temuan tersebut ditemukan pada Formasi Kabuh berumur plestosen tengah (Widianto dkk., 2001:5).

Alat tulang nomor 44 berupa tulang kaki (proximal tibia) rusa (cervidae sp.). Spesimenalattulangtersebuttidakdiketahui keberadaannya, sehingga pengukuran dan deskripsi tidak penulis lakukan. Kalau melihat gambar/ foto, kemungkinan teknik yang digunakan adalah teknik gabungan antara pecah, belah, dan pangkas. Teknik pecah digunakan untuk memotong bagian tulang utuh menjadi dua bagian, kemudian dibelah dengan pukulan dari arah proximal tulang menjadi dua bagian searah panjang tulang, terakhir pangkasan di bagian tengah untuk membentuk tajaman dengan pukulan miring ke arah ujung distal.

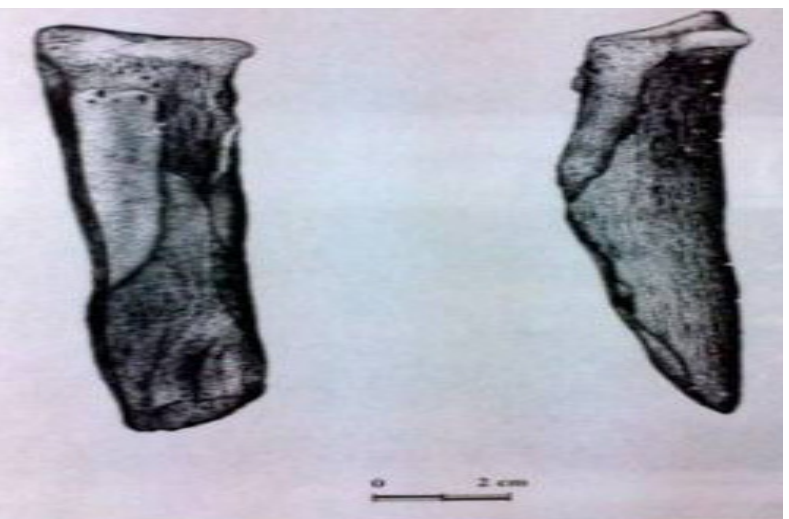

Gambar 14. Spatula terbuat dari tulang kering (Sumber: Widianto dkk, 2001)

\section{Alat tulang dari Situs Patiayam}

Alat tulang nomor 45 berupa sebuah spatula. Ditemukan di kotak ekskavasi TP 4 pada lapisan konglomerat. Alat tulang ini ditemukan bersama empat buah artefak lainnya, yaitu tiga buah kapak perimbas (chopper) dan sebuah batu pukul (Siswanto dalam Anonim, 2014:23). Penulis tidak melakukan pendeskripsian dan kami tidak menampilkan foto, sumber pustaka tidak mencantumkan foto dan deskripsi.

Alat tulang nomor 46 berupa spatula yang terbuat dari tulang kaki binatang. Artefak ini memiliki ukuran panjang 110,71 $\mathrm{mm}$, lebar 49,95 mm, dan tebal 32,48 $\mathrm{mm}$. Kondisi artefak ini telah mengalami kerusakan di beberapa bagian, terutama pada bagian tajamannya. Jejak teknologi yang terlihat berupa bekas pangkasan pada salah satu bagian yang merupakan bagian tajaman yang memiliki bentuk melengkung dan melebar.

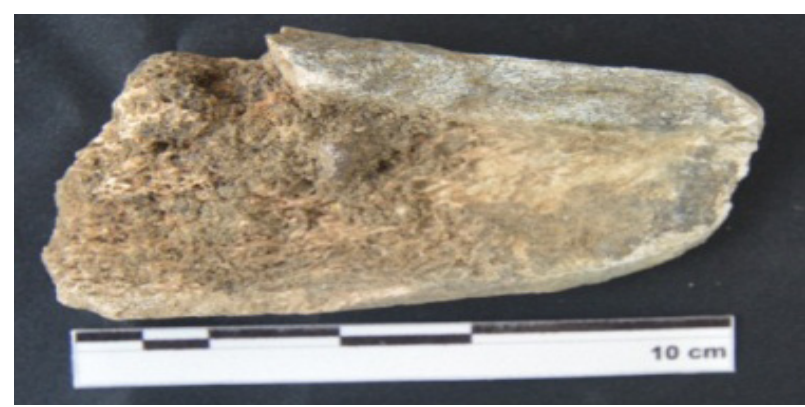

Gambar 15. Spatula terbuat dari tulang kaki binatang (dokumentasi Ilham) 
Alat tulang nomor 47 berupa lancipan yang terbuat dari tulang telapak kaki depan (Proximal metacarpal bovidae). Alat tulang ini merupakan temuan penduduk di Sungai Gandu, Desa Terban, Kecamatan Jekulo, Kudus. Alat tulang ini memiliki ukuran panjang $174,57 \mathrm{~mm}$, lebar $56,90 \mathrm{~mm}$, dan tebal $49,54 \mathrm{~mm}$. Tulang ini dipangkas menjadi dua bagian, kemudian dilakukan pemangkasan dengan kemiringan $40^{\circ}$ dari tengah tulang menuju ke arah distal denganpanjang pecahan 62,87 $\mathrm{mm}$. Pangkasan ini merupakan pemangkasan untuk pembuatan tajaman. Kondisi artefak ini sekarang memperlihatkan kerusakan pada baqian uiuna lancipan. membelah tulang searah panjang tulang. Artefak ini memiliki tajaman pada kedua ujungnya, satu bagian berbentuk meruncing (lancipan) dan bagian lain berbentuk membulat pipih melebar (spatula). Pada bagian tengah sisi lateral artefak ini terdapat bekas pengerjaan yang membentuk kurva, tetapi untuk mengetahui teknik pembuatan bagian ini diperlukan penelitian yang lebih mendalam. Tidak diketahui dengan pasti apakah digosok ataukah dipangkas. Bentuk tersebut mirip dengan artefak mata tombak berbahan duri ikan pari dari Ngandong.

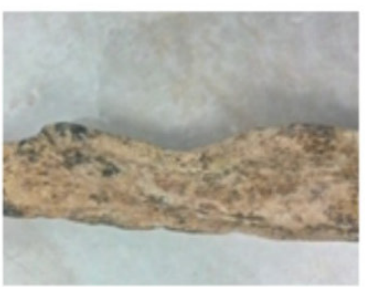

Jejak pengerjaan

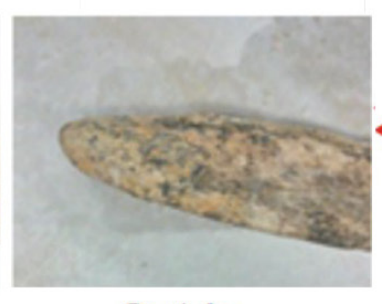

Spatula

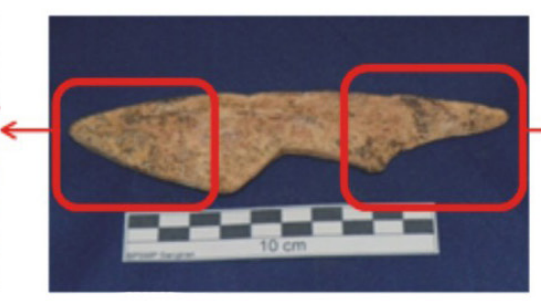

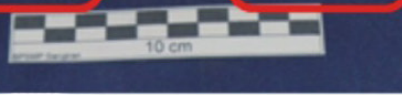

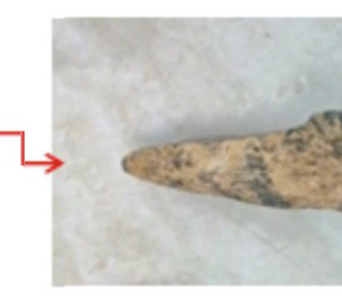

Lancipan

Gambar 17. Alat tulang berujung ganda: lancipan dan spatula, dengan jejak pengerjaan di bagian lateral (dokumentasi Ilham)

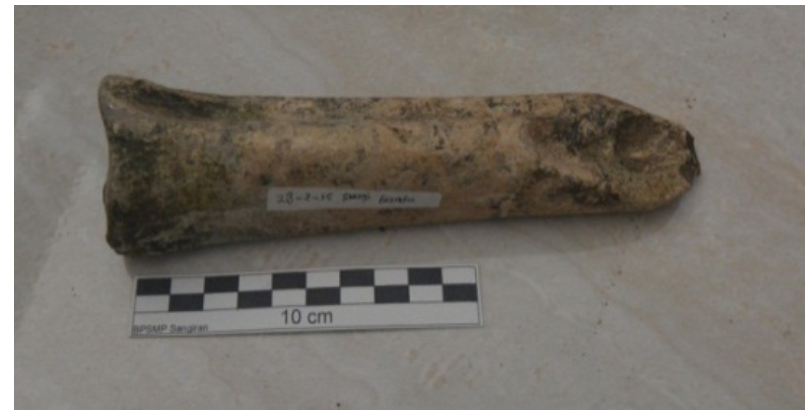

Gambar 16. Lancipan terbuat dari tulang kaki bovidae (dokumentasi Ilham)

Alattulang nomor 48 berupalancipan atau spatula terbuat dari tulang kaki binatang. Artefak ini memiliki ukuran panjang $149,51 \mathrm{~mm}$, lebar 34,13 $\mathrm{mm}$, dan tebal $13,35 \mathrm{~mm}$. Artefak ini memperlihatkan bentuk penampang yang pipih akibat pemangkasan yang

\section{Bahan baku, Teknologi, dan Tipologi alat tulang}

Informasi yang akan penulis sampaikan berkaitan dengan empat hal: bahan baku, teknologi, dan tipologi alat tulang masa Plestosen di Jawa, serta lokasi penemuannya. Informasi bahan baku berkaitan dengan jenis bintang dan bagian tulang yang digunakan sebagai alat. Pembahasan tentang teknologi berkaitan dengan teknik yang digunakan dalam pembuatan alat tulang. Sementara tipologi berhubungan dengan bentuk umum, letak tajaman, dan jejak pakai alat tulang. Terakhir, informasi lokasi penemuan masing-masing alat tulang di Jawa. Berikut ini hasil identifikasi yang 
telah penulis lakukan terhadap alat tulang dari beberapa situs di Jawa:

\section{Bahan baku alat tulang di Jawa}

Analisis taksonomi telah digunakan untuk mengetahui bagian tulang dan jenis bintang yang diamati. Pengamatan dilakukan secara makroskopis dengan menggunakan gambar/ foto dan fosil koleksi BPSMP Sangiran sebagai pembanding dan sebagai dasar penetapan jenis binatang dan bagian tulang yang diamati. Berdasarkan pembacaan literatur dan pengamatan/ identifikasi yang dilakukan terhadap 48 spesimen alat tulang dari beberapa situs plestosen di Jawa, telah didapatkan sebanyak 13 jenis komponen tulang yang dijadikan bahan baku pembuatan alat tulang, termasuk diantaranya hanya disebut sebagai tulang binatang, tulang panjang, dan tulang kaki. Komponen tulang tersebut terdiri dari:

1. Tulang kering (tibia) sebanyak enam buah yaitu tiga Bovidae, satu Bos sp. (sapi), satu Cervus sp. (rusa), dan satu Cervidae (rusa)

2. Tulang lengan atas (humerus) sebanyak tiga buah, yaitu Bibos palaesondaicus (banteng), Cervus $s p$. (rusa), dan Sus sp. (babi)

3. Tulang paha (femur) Cervus sp. (rusa)

4. Tanduk (antler) sebanyak sembilan buah, yaitu lima Cervus sp. (rusa), satu Cervus Hippelaphus (rusa), dua Cervidae (rusa), dan satu Cervus (axis) Lydekkerii (rusa)

5. Telapak kaki depan (metacarpal) sebanyak empat buah, yaitu satu Rhinoceros (badak), sebuah Bos sp. (sapi), dan dua Bovidae

6. Tulang hasta (radius) lima Bovidae
7. Tulang rusuk (costae) sebanyak dua buah, yaitu Elephantidae (gajah) dan Bovidae

8. Tulang telapak kaki belakang (metatarsal) dua Bovidae

9. Tulang panjang sebanyak tiga buah, yaitu dua mamalia (binatang menyusui) dan satu Bovidae

10. Tulang kaki sebanyak dua buah, yaitu dua Bovidae, dua mamalia, dan satu spesimen yang tidak dapat diidentifikasi (tulang kaki binatang)

11. Sebuah spesimen terbuat dari gading Elephantidae (gajah)

12. Sebuah spesimen terbuat dari duri ikan pari

13. Sebuah spesimen tidak dapat diidentifikasi jenis binatangnya

\section{Teknologi alat tulang dari Jawa}

Analisis teknologi pembuatan telah dilakukan untuk mengetahui teknik pembuatan artefak. Pengamatan dilakukan terhadap bentuk pecahan (frakturasi) dan jejak pemukulan. Pengamatan terhadap bentuk pecahan pada tulang dilakukan untuk membedakan antara tulang yang merupakan jejak akibat aktivitas manusia dengan yang alamiah. Tulang yang pecah akibat aktivitas manusia dipukul dengan alat atau benda lain, akan meninggalkan bekas berupa titik pukul tulang tersebut. Karakteristik dari titik pemukulan adalah adanya wilayah pukul yang memiliki morfologi lekukan melingkar atau setengah lingkaran pada permukaan tulang dengan bentuk tepian bergerigi ataupun bertingkat namun tetap memiliki kesamaan dengan permukaan kortikalnya. Tulang yang dijadikan alat memiliki ciri-ciri yang terletak pada bagian tajaman, yaitu berkaitan dengan bentuk dan pembuatan tajaman. Jejak 
penajaman biasanya berupa striasi atau goresan yang berjajar di bagian tajaman dan kilapan akibat pengerjaan penghalusan. Beberapa teknik yang digunakan dalam pembuatan alat tulang diantaranya adalah teknik pangkas, teknik gosok, teknik pecah, dan teknik gabungan pangkas-gosok, serta gabungan lebih dari dua teknik. Analisis jejak pakai bertujuan untuk mengetahui apakah alat tersebut telah dipergunakan. Pengamatan dilakukan terhadap jejak pakai pada tajaman. Tulang yang dipakai atau digunakan akan meninggalkan jejak berupa retus pakai, goresan pada permukaan, kilapan, dan keausan pada tajaman (Lyman, 1994: 326, dalam Kusno, 2006:19).

Teknologi pembuatan alat tulang dari situs Pleistosen di Jawa secara umum memperlihatkan penggabungan lebih dari satu teknik. Dari 48 spesimen yang penulis amati, sebagian besar dibuat dengan teknik pecah, kemudian dilakukan pangkasan (pecah dan pangkas). Sebagian lagi ada yang memperlihatkan teknik gosok pada tahap akhir. Ada juga yang menggabungkan teknik tekan dan belah setelah pemecahan tulang. Berikut teknik yang digunakan dalam membuat alat tulang pada 48 spesimen yang kami amati, yaitu:

1. Pangkas: pangkasan terjal dilakukan terhadap tulang utuh untuk membagi dua tulang, bekas pangkasan digunakan sebagai tajaman. Spesimen yang memperlihatkan teknik ini adalah spesimen nomor 12 , no. 13 , no. 16 , no. 39 , dan spesimen nomor 35 . Penggunaan teknik pangkasan karena memang spesimen tersebut merupakan ujung tanduk. Jadi, pemangkasan dilakukan hanya untuk membentuk tajaman.

2. Pecah dan pangkas: tulang utuh dipecah menjadi dua, pukulan diarahkan pada bagian diaphisys atau mesial (bagian tengah) tulang. Setelah itu, salah satu bagian ephipisys (proximal atau distal) tulang diambil dan dilakukan pangkasan untuk membentuk tajaman sesuai keinginan. Pukulan diarahkan di tengah tulang dengan sudut kemiringan tertentu ke arah berlawanan dengan bagian tengah (ephipisys). Alat tulang yang dihasilkan melalui teknik ini sebanyak 25 spesimen, yaitu spesimen nomor 6 , no. 7 , no. 9 , no. 10 , no. 11 , no. 14 , no. 15 , no. 17 , no. 18 , no. 19 , no. 20 , no. 22 , no. 23 , no. 27 , no. 29 , no. 31 , no. 32 , no. 36 , no. 37 , no. 38 , no. 41 , no. 42 , no. 43 , no. 46 , dan spesimen nomor 47.

3. Pecah, tekan, pangkas, dan gosok: tulang utuh dipecah menjadi dua, pukulan diarahkan pada bagian diaphisys atau mesial (bagian tengah) tulang. Kemudian dilakukan tekanan pada bagian pecahan tulang hingga didapatkan bagian yang terlepas dari tulang intinya. Selanjutnya dilakukan pangkasan untuk membentuk tajaman, dan akhirnya dilakukan penggosokan untuk menghaluskan tajaman. Alat yang dihasilkan melalui teknik ini adalah spesimen nomor 25.

4. Pecah, belah, dan pangkas: tulang utuh dipecah menjadi dua, pukulan diarahkan pada bagian diaphisys atau mesial (bagian tengah) tulang, setelah itu tulang dibelah secara vertikal untuk mendapatkan bagian tulang yang pipih. Selanjutnya dilakukan pembuatan tajaman dengan cara pemangkasan pada salah satu 
ujungnya. Alat tulang yang dihasilkan melalui teknik ini, yaitu spesimen nomor 21 , nomor 25 , dan spesimen nomor 44.

5. Pecah, pangkas, belah, dan gosok: tulang utuh dipecah menjadi dua, pukulan diarahkan pada bagian tengah tulang. Kemudian dilakukan pangkasan untuk membuang bagian tengah tulang. Setelah itu, tulang dibelah secara vertikal untuk medapatkan bagian tulang yang pipih. Selanjutnya dilakukan pembuatan tajaman dengan cara pemangkasan dan penggosokan untuk menghaluskan tajaman. Alat tulang yang dihasilkan melalui teknik ini, yaitu spesimen nomor 21 , 25, dan 40.

Alat tulang yang memperlihatkan jejak pemakaian yaitu spesimen nomor 8,13 , dan 21. Spesimen nomor 8 berupa lancipan yang terbuat dari tulang kering (tibia) Bos sp.(sapi). Spesimen nomor 13 berupa lancipan yang terbuat dari tanduk (antler) Cervus hippelaphus (rusa). Spesimen nomor 21 berupa spatula/ pisau yang terbuat dari tulang kaki Bovidae.

\section{Tipologi alat tulang dari Jawa}

Berdasarkan bentuk dan letak tajaman 48 spesimen alat tulang dari situs Plestosen di Jawa yang penulis amati, terdapat tiga jenis alat tulang, yaitu: pisau, lancipan, alat berujung ganda, dan sebuah diperkirakan mata tombak. Pisau sebanyak satu atau dua buah, lancipan 22 buah, spatula 12 buah, artefak berujung ganda (spatula dan lancipan) yang ditunjukkan oleh spesimen nomor 48 dari Patiayam, dan sebuah mata tombak yang ditunjukkan oleh spesimen nomor 34 dari Ngandong. Disamping itu terdapat sebuah variasi dari lancipan, yaitu lancipan berujung ganda (spesimen nomor 20). Perlu juga penulis sampaikan bahwa spesimen nomor 21, 34 dan 48 masih menjadi perdebatan. Spesimen nomor 21 dari segi bentuk tajaman yang pipih dan melebar, maka alat ini adalah spatula. Tetapi terdapat kilapan atau bagian yang halus pada tajamannya kemungkinan bekas pemakaian. Kedua sisi tajamannya bersentuhan dengan sesuatu, sehingga menghasilkan jejak kilapan yang simetris pada tajamannya. Spesimen no. 34 telah lama menjadi perdebatan para ahli. Alat tulang no. 34 memperlihatkan bentuk dan teknologi yang berasal dari masa yang lebih muda, seperti yang diperlihatkan oleh alat tulang dari situs Magdaleine (Dordogne, Prancis) yang dikenal dengan budaya Magdalenian yang berkembang dari masa 40.000-10.000 tahun lalu. Sementara spesimen nomor 48 memperlihatkan bentuk modifikasi yang sama dengan spesimen nomor 34 pada bagian sisi bagian tengahnya.

\section{PENUTUP}

Homo erectus di Jawa telah membuat dan memakai alat tulang. Mereka menggunakan teknik pecah, teknik pangkas, teknik belah, dan penggosokan, serta gabungan teknik-teknik itu dalam membuat alat tulang. Mereka telah membuat pisau, spatula, lancipan, alat berujung ganda (lancipan dan spatula), dan mata tombak. Diantara jenis alat tulang tersebut terdapat dua spesimen yang masih perlu dikaji ulang berdasarkan teknologi pembuatan tajaman yang memperlihatkan teknologi yang tidak 
sama dengan spesimen pada umumnya, yaitu spesimen nomor 34 dan 48 .

Bahan baku yang digunakan terdiri atas 12 jenis komponen anatomis binatang, yaitu: tulang kering (tibia), tulang lengan atas (humerus), tulang paha (femur), tanduk (antler), telapak kaki depan (metacarpal), tulang hasta (radius), tulang rusuk (costae), telapak kaki belakang (metatarsal), gading (incisivus), duri ikan, tulang panjang, dan tulang kaki. Tulang-tulang yang dimanfaatkan menjadi bahan alat berasal dari berbagai jenis binatang, yaitu: Cervus sp. (rusa), Cervus hippelaphus (rusa), Cervus (axis) lydekkerii (rusa), Sus sp. (babi), Bos sp. (sapi), Rhinoceros (badak), Elephantidae (gajah), Bovidae, Bibos palaeosondaicus dan ikan pari. Alat tulang di Jawa sementara ini ditemukan di situs Sangiran (Sragen dan Karanganyar), situs Ngandong (Blora), situs Sambungmacan (Sragen), situs Bringin (Ngawi), dan situs Patiayam (Kudus dan Pati). 


\section{DAFTAR PUSTAKA}

Abdullah, Ilham. 2013. "Alat Tulang dari Sangiran: Bahan Baku, Teknologi, Tipologi, Kronologi, dan Sebarannya", dalam Jurnal Sangiran No. 2. Sragen: Balai Pelestarian Situs Manusia Purba Sangiran.

Abdullah, Ilham. 2014. "Alat Tulang dari Situs Sangiran", dalam Jurnal Penelitian Arkeologi Papua, Vol. 6, Edisi No. 2, November 2014. Jayapura: Balai Arkeologi Jayapura.

Abdullah, Ilham. 2014. "Artefak Homo Erectus di Situs Sambungmacan, Sragen, Jawa Tengah:Eksistensi dan Teknik Pembuatan”, dalam Jurnal Sangiran No. 3. Sragen: Balai Pelestarian Situs Manusia Purba Sangiran.

Anonim. 2014. Rapat Koordinasi Pengembangan Hasil Penelitian Arkeologi Tahun 2014 di Hotel Mutiara I 18 - 21 Februari 2014. Balai Arkeologi Yogyakarta.

Fauzi, dkk. 2013. "Penelitian Situs Matar, Kecamatan Margomulyo, Bojonegoro". Laporan Penelitian Balai Pelestarian Situs Manusia Purba Sangiran.

Kusno, Abi. 2006. "Pemanfaatan Bovidae di Situs Song Terus, Punung, Jawa Timur". Skripsi. Jakarta: Jurusan Arkeologi, Fakultas IImu Budaya, Universitas Indonesia.

Notosusanto, N. dan Poesponegoro, M. D. 2010. Sejarah Nasional Indonesia I. Edisi Pemutakhiran. Jakarta: Balai Pustaka.

Simanjuntak, Harry Truman dan Widianto, Harry. 2012. Indonesia dalam Arus Sejarah. Jakarta: PT. Ichtiar Baru van Hoeve kerjasama Kementerian Pendidikan dan Kebudayaan.

Widianto, Harry. 2001. "Laporan Peninjauan Kepurbakalaan di Kecamatan Bringin, Kabupaten Ngawi, Jawa Timur". Yogyakarta: Balai Arkeologi Yogyakarta.

Widianto, Harry dan Hidayat, M. 2010. Laporan Eksplorasi Situs Budaya Manusia Purba di Situs Ngandong, Blora. Sragen: Balai Pelestarian Situs Manusia Purba Sangiran 